\title{
PENGEMBANGAN SISTEM MANAJEMEN PENGETAHUAN DI ORGANISASI ASOSIASI ALUMNI PROGRAM BEASISWA AMERIKA - INDONESIA (ALPHA-I)
}

\author{
Muhammad Nurwegiono $^{* 1}$, Sri Nurdiati ${ }^{2}$, Sony Hartono Wijaya ${ }^{3}$ \\ 1,2,3 Departemen Ilmu Komputer, Fakultas Matematika dan Ilmu Pengetahuan Alam, Institut Pertanian Bogor \\ Email: ${ }^{1}$ muhammad_nurwegiono@apps.ipb.ac.id, ${ }^{2}$ nurdiati@ipb.ac.id, ${ }^{3}$ sony@apps.ipb.ac.id \\ *Penulid Korespondesnsi
}

(Naskah masuk: 22 Juli 2019, diterima untuk diterbitkan: 27 April 2020)

\begin{abstract}
Abstrak
Organisasi ALPHA-I (Asosiasi Alumni Program Beasiswa Amerika - Indonesia) memiliki anggota lebih dari 400 orang yang tersebar di sepuluh daerah di Indonesia. Jumlah alumni penerima beasiswa pendidikan dari United States Agency for International Development (USAID) akan bertambah setiap tahun dan akan tergabung di organisasi ini. Hasil observasi menunjukkan bahwa organisasi ALPHA-I memiliki dua masalah utama. Permasalahan pertama adalah ALPHA-I belum menyediakan sarana berbagi pengetahuan tacit pada lima fokus bidang beasiswa USAID. Permasalahan kedua adalah pengetahuan explicit karyawan seperti Standar Operasional Prosedur (SOP), laporan kegiatan, laporan hasil rapat, daftar mitra dan dokumen penting lainnya yang masih dibukukan. Permasalahan tersebut dapat diselesaikan dengan membuat sistem manajemen pengetahuan. Tujuan penelitian ini adalah mengembangkan sistem manajemen pengetahuan yang dapat memudahkan proses menangkap, mengembangkan, membagikan, dan memanfaatkan pengetahuan tacit alumni dan pengetahuan explicit karyawan di organisasi ini. Penelitian ini dilakukan dengan menggunakan metode Knowledge Management System Life Cycle (KMSLC). Hasil dari penelitian ini adalah sistem manajemen pengetahuan yang dibangun dengan framework PHP dan MySQL sebagai Relational Database Management System (RDBMS) berbasis website. Hasil pengujian Black box dari 36 kasus uji yang telah dilakukan menyatakan bahwa semua fungsi pada sistem berjalan sesuai dengan perintah yang diberikan.
\end{abstract}

Kata kunci: ALPHA-I, sistem manajemen pengetahuan, knowledge management system life cycle (KMSLC).

\section{THE DEVELOPMENT OF KNOWLEDGE MANAGEMENT SYSTEM AT AN ORGANIZATION ALUMNI ASSOCIATION OF US - INDONESIA SCHOLARSHIP PROGRAMS (ALPHA-I)}

\begin{abstract}
The ALPHA-I Organization (Alumni Association of US - Indonesia Scholarship Programs) has more than 400 members that have spread in ten regions (chapters) in Indonesia. The number of alumni who receive educational scholarships from United States Agency for International Development (USAID) will increase every year and will join this organization. The result of observation to ALPHA-I organization showed that there are two main problems. The first problem is ALPHA-I organization did not provide equipment for the alumni to share their tacit knowledge on five focused areas of USAID scholarships. The second problem is the explicit knowledge of employees to record the Standard Operational Procedure (SOP), activity reports, meeting report, partner list, and other relevant documents were written by books. These problems can be solved by creating a knowledge management system. The purpose of this study is to develop a knowledge management system that can facilitate the process of creation, development, share, and utilize tacit knowledge of alumni and explicit knowledge of employees at ALPHA-I. This research was conducted using the Knowledge Management System Life Cycle (KMSLC) method. The result of this study was a knowledge management system that was built with PHP framework and MySQL-as a Relational Database Management System (RDBMS) based on website. The result of black box testing from 36 case studies demonstrated that all functions in the system run according to the commands given.
\end{abstract}

Keywords: ALPHA-I, knowledge management system, knowledge management system life cycle (KMSLC). 


\section{PENDAHULUAN}

Menurut Peraturan Menteri Hukum dan Hak Asasi Manusia (HAM) Republik Indonesia Nomor 6 Tahun 2014, asosiasi (perkumpulan) adalah kumpulan orang yang mendirikan asosiasi untuk menjalankan kesamaan tujuan tertentu di bidang sosial, keagamaan, kemanusiaan, dan tidak memberikan profit kepada anggotanya. Alumni merupakan orang-orang yang menyelesaikan pendidikan dari sekolah, akademi, perguruan tinggi atau universitas (Kirana \& Wahdaniyah, 2018). Alumni berperan penting dalam mendorong sistem pendidikan yang lebih baik, karena pengetahuan dan pengalaman yang sudah didapatkan (Kirana \& Wahdaniyah, 2018).

Salah satu asosiasi alumni yang berperan dalam mendorong sistem pendidikan yang lebih baik di Indonesia adalah Asosiasi Alumni Program Beasiswa Amerika - Indonesia (ALPHA-I). ALPHA-I merupakan organisasi penerima beasiswa dari United States Agency for International Development (USAID). Alumni USAID mulai membentuk perkumpulan alumni di awal tahun 2011. Nama ALPHA-I terbentuk sebagai organisasi di Jakarta pada tahun 2012 yang telah berbadan hukum dari Menteri Hukum dan Hak Asasi Manusia. Organisasi ini memiliki alumni lebih dari 400 orang yang bergabung di ALPHA-I dan sudah tersebar di sepuluh daerah (chapters) dari Sumatera sampai Papua. Jumlah alumni penerima beasiswa USAID akan bertambah terus setiap tahunnya dan bergabung di organisasi ALPHA-I. USAID fokus memberikan beasiswa kepada lima bidang yaitu: pendidikan, kesehatan, lingkungan hidup, pertumbuhan ekonomi, demokrasi HAM dan tata kelola.

Hasil observasi menunjukkan bahwa organisasi ALPHA-I memiliki dua masalah, pertama selama ini dari banyaknya jumlah alumni USAID yang bergabung di ALPHA-I ternyata belum ada sarana untuk berbagi pengetahuan tacit terhadap lima fokus bidang beasiswa yang diberikan USAID. Pengetahuan tacit merupakan pengetahuan yang berada di pikiran setiap orang (Bolisani \& Handzic, 2015). Kedua pengetahuan explicit karyawan yang bekerja di organisasi ALPHA-I seperti Standar Operasional Prosedur (SOP), laporan kegiatan, laporan hasil rapat, daftar mitra dan dokumen penting lainnya masih dibukukan. Laporan-laporan tersebut setiap tahun dikumpulkan dan dimasukkan ke dalam kotak dokumen, sehingga jika karyawan lain yang membutuhkan informasi tersebut harus mencari terlebih dahulu dimana laporan tersebut disimpan dan hal ini cukup menyulitkan jika ternyata laporan tersebut hilang atau dipinjam. Karyawan meninggalkan organisasi ini juga menjadi permasalahan, karena pengetahuan jadi ikut pergi atau hilang. Pengetahuan explicit merupakan pengetahuan yang sudah terdokumentasikan dalam bentuk tertulis (Siswanto, 2014). Sistem manajemen pengetahuan diperlukan dalam menyelesaikan kedua masalah di organisasi ALPHA-I. Sistem Manajemen Pengetahuan atau Knowledge Management System merupakan penggabungan teknologi dan mekanisme yang dibangun untuk membantu proses manajemen pengetahuan (Becerra-Fernandez \& Sabherwal, 2010).

Manajemen pengetahuan dianggap sebagai ilmu yang semakin penting untuk mempromosikan penciptaan pengetahuan, berbagi pengetahuan, dan pemanfaatan pengetahuan yang baik untuk organisasi (Alipour, Idris, \& Karimi, 2011). Penelitian terdahulu mengenai sistem manajemen pengetahuan dalam bidang organisasi menjelaskan teknologi informasi mendukung pengelolaan pengetahuan pada organisasi alumni perguruan tinggi yang bertujuan menghubungkan perusahaan atau instansi dengan lulusan academia (Prayitno, Kusrini, \& Sudarmawan, 2017).

Organisasi ALPHA-I belum mengelola pengetahuannya dari kedua permasalahan diatas, sehingga berbagi pengetahuan belum terjadi. Oleh sebab itu penelitian ini bertujuan mengembangkan sistem manajemen pengetahuan yang dapat memudahkan proses menangkap, mengembangkan, membagikan, dan memanfaatkan pengetahuan dari pengetahuan tacit alumni dan pengetahuan explicit karyawan.

\section{METODE PENELITIAN}

Metode yang digunakan dalam membangun sistem manajemen pengetahuan di organisasi ALPHA-I yaitu menggunakan metode Knowledge Management System Life Cycle (KMSLC) yang diadopsi dari Awad \& Ghaziri (2010) dengan tahapan penelitian yang dilakukan mulai dari menangkap pengetahuan hingga verifikasi dan validasi sistem manajemen pengetahuan. Tahapan pengembangan sistem ini dapat dilihat pada Gambar 1.

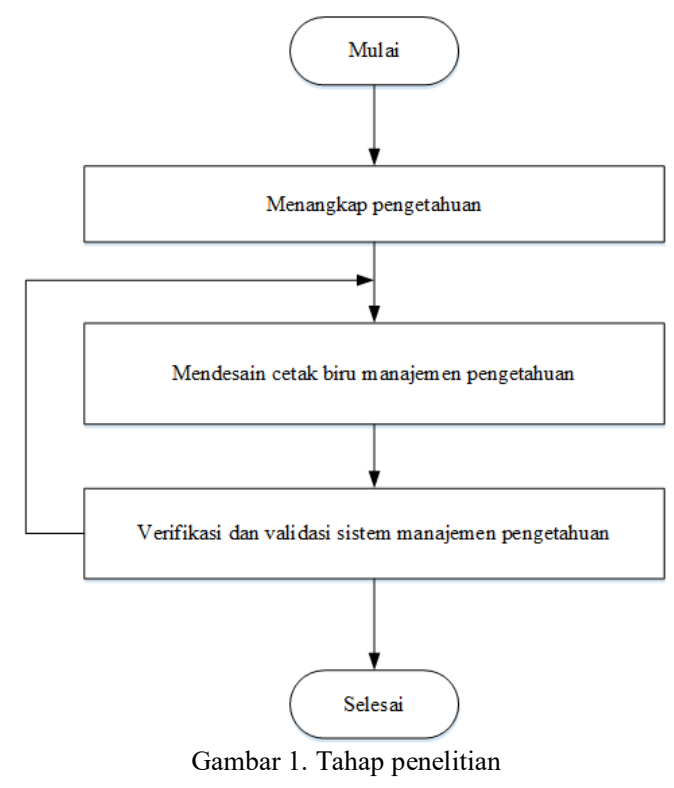



berikut:

Setiap tahapan dapat dijelaskan sebagai

1. Menangkap pengetahuan.

Tahap ini mulai dilakukan penangkapan pengetahuan pakar. Pengetahuan yang baru harus diidentifikasi terlebih dahulu sehingga menjadi pengetahuan yang bernilai.

2. Mendesain cetak biru manajemen pengetahuan. Tahap ini melakukan perancangan KMS.

3. Verifikasi dan validasi sistem manajemen pengetahuan. Tahap ini melakukan pengujian pengetahuan dari KMS yang dibangun.

Tahap mengevaluasi infrastruktur dan membentuk tim manajemen pengetahuan tidak dilakukan, karena dalam proses mendapatkan pengetahuan yang ada di organisasi ALPHA-I bisa ditanyakan langsung kepada General Manager tanpa perlu melibatkan karyawan lainnya dalam mempercepat proses penelitian ini. Tahap implementasi tidak dilakukan, karena pada tahap ini bertujuan menjalankan sistem ke dalam situasi dan operasi yang sebenarnya. Jika tahap implementasi dilakukan, maka diperlukan tahap evaluasi sistem.

\section{HASIL DAN PEMBAHASAN}

\subsection{Menangkap Pengetahuan}

Berdasarkan hasil studi literatur, observasi dan wawancara dengan General Manager di organisasi ALPHA-I, dan alumni. Pendekatan wawancara dapat dilakukan secara formal maupun informal (Narendra, Pradeep, \& Prabhakar, 2017). Hasil identifikasi pengetahuan yang diperoleh dapat dilihat pada Tabel 1.

Tabel 1. Identifikasi pengetahuan

\begin{tabular}{|c|c|c|c|c|c|}
\hline \multirow[b]{2}{*}{ No } & \multirow[b]{2}{*}{ Pengetahuan } & \multicolumn{2}{|c|}{ Pemilik } & \multicolumn{2}{|c|}{ Penyimpanan } \\
\hline & & $\begin{array}{l}\text { Alu } \\
\text { mni }\end{array}$ & $\begin{array}{l}\text { Kary } \\
\text { awan }\end{array}$ & $\begin{array}{l}\text { Hard } \\
\text { Copy }\end{array}$ & $\begin{array}{l}\text { Soft } \\
\text { Copy }\end{array}$ \\
\hline 1 & $\begin{array}{l}\text { Inovasi (ide) } \\
\text { terkait bidang } \\
\text { pendidikan, } \\
\text { kesehatan, } \\
\text { lingkungan } \\
\text { hidup, } \\
\text { pertumbuhan } \\
\text { ekonomi, } \\
\text { demokrasi } \\
\text { HAM dan tata } \\
\text { kelola }\end{array}$ & $\sqrt{ }$ & & & \\
\hline 2 & Keahlian & $\sqrt{ }$ & & & \\
\hline 3 & Pengalaman & $\sqrt{ }$ & & & \\
\hline 4 & $\begin{array}{l}\text { Standar } \\
\text { Operasional } \\
\text { Prosedur } \\
\text { (SOP) }\end{array}$ & & $\sqrt{ }$ & $\sqrt{ }$ & $\sqrt{ }$ \\
\hline 5 & $\begin{array}{l}\text { Laporan } \\
\text { kegiatan }\end{array}$ & & $\sqrt{ }$ & & $\sqrt{ }$ \\
\hline 6 & $\begin{array}{l}\text { Laporan hasil } \\
\text { rapat }\end{array}$ & & $\sqrt{ }$ & & $\sqrt{ }$ \\
\hline 7 & Daftar mitra & & $\sqrt{ }$ & & $\sqrt{ }$ \\
\hline 8 & Press release & & $\sqrt{ }$ & & $\sqrt{ }$ \\
\hline
\end{tabular}

Berdasarkan hasil identifikasi pengetahuan pada Tabel 1, maka pengetahuan yang ditangkap dapat dibagi menjadi dua yaitu pengetahuan tacit dan pengetahuan explicit.

\section{Pengetahuan tacit}

Pengetahuan ditangkap melalui wawancara dengan melibatkan pakar, dalam hal ini adalah alumni berpengalaman lebih dari lima tahun terhadap kelima bidang pendidikan, kesehatan, lingkungan hidup, pertumbuhan ekonomi, demokrasi HAM dan tata kelola. Pengetahuan tacit alumni berupa pemikiran atau ide dari kelima bidang kepakaran yang dimiliki oleh organisasi ALPHA-I. Pengetahuan tacit dari alumni akan diverifikasi dan divalidasi oleh pakar. Pakar bidang pendidikan tidak bisa verifikasi pengetahuan alumni bidang lain. Pakar bidang pendidikan hanya bisa verifikasi dan validasi pengetahuan alumni bidang pendidikan juga.

\section{Pengetahuan explicit}

Pengetahuan yang bersumber dari berbagai dokumen tertulis berkaitannya dengan pekerjaan karyawan di organisasi ALPHA-I. Pengetahuan ini dapat berupa tambah dokumen atau unggah dokumen elektronik ke dalam sistem dan tersimpan dalam repositori sehingga dapat dibaca secara online atau unduh kembali oleh karyawan. Dokumen tersebut berupa Standar Operasional Prosedur (SOP), laporan kegiatan, laporan hasil rapat, daftar mitra, dan press release.

\subsection{Mendesain Cetak Biru Manajemen Pengetahuan}

\subsubsection{Kodifikasi Pengetahuan}

Kodifikasi pengetahuan dapat dikonversikan ke dalam bentuk dokumen serta menyajikan dan mengorganisir pengetahuan yang dapat digunakan sebagai pengetahuan pengambilan keputusan (Awad \& Ghaziri, 2010). Kodifikasi pengetahuan dilakukan dengan menggunakan Knowledge Map. Knowledge map merupakan gambaran visual dari pengetahuan tacit maupun explicit yang saling terhubung antara satu dengan yang lain dalam suatu rangkaian proses. Penelitian ini Knowledge Map dibuat berdasarkan pengetahuan yang ada di organisasi ALPHA-I yaitu pengetahuan tacit alumni dan pengetahuan explicit karyawan. Setiap pengetahuan dipetakan berdasarkan pengetahuan yang dimiliki oleh organisasi tersebut. Kodifikasi knowledge map, alumni memiliki pengetahuan terkait ide terhadap kelima bidang kepakaran dari organisasi ALPHA-I, keahlian, dan pengalaman. Karyawan memiliki pengetahuan terkait dokumen SOP, laporan kegiatan, laporan hasil rapat, daftar mitra, dan press release. Hasil kodifikasi knowledge map dapat dilihat pada Gambar 2. 


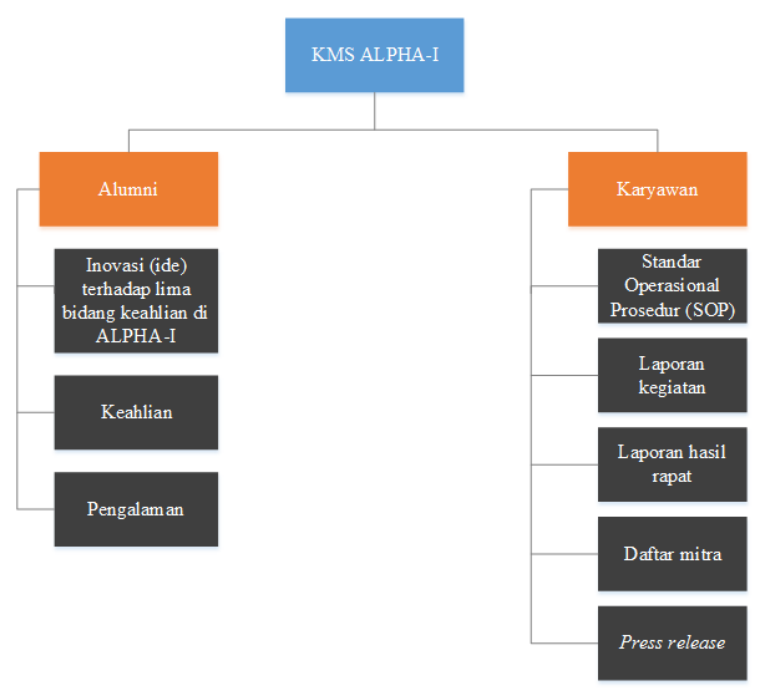

Gambar 2. Hasil Kodifikasi Knowledge Map

Pengetahuan yang sudah terkumpul akan dimasukkan dalam suatu sistem manajemen pengetahuan berbentuk repositori. Pengetahuan disimpan ke dalam repositori dengan pembobotan Term Frequency (TF) dan Inverse Document Frequency (IDF). Keseluruhan proses pembobotan pengetahuan yang direpresentasikan dengan dokumen dan memuat kembali pengetahuan dilakukan dengan menggunakan Library Zend Lucene. Lucene adalah library untuk Information Retrieval (IR) atau temu kembali informasi yang memiliki kemampuan tinggi dalam pengindeksan dan pencarian dokumen. Pengindeksan merupakan suatu proses dalam membangun basis data indeks dari koleksi dokumen. Pengindeksan dilakukan untuk dokumen sebelum pencarian dilakukan.

Tahapan dari pengindeksan adalah sebagai berikut:

1. Parsing merupakan suatu cara pengambilan katakata dari himpunan dokumen.

2. Stoplist merupakan metode pembuangan kata.

3. Stemming merupakan proses pemotongan suatu kata menjadi bentuk dasar.

4. Term Weighting dan Inverted File merupakan metode pemberian bobot pada istilah.

\subsubsection{Perancangan Sistem Manajemen Pengetahuan}

\section{Kebutuhan fungsional}

Kebutuhan fungsional perangkat lunak dari sistem manajemen pengetahuan organisasi ALPHAI meliputi fitur pengetahuan, fitur validasi pengetahuan, fitur dokumen, fitur agenda kegiatan, fitur agenda rapat, fitur mitra, fitur konsultasi, fitur tanya jawab, dan fitur kontak. Fitur pengetahuan memfasilitasi alumni dalam mendokumentasikan dan berbagi pengetahuan-pengetahuan tacit. Fitur validasi pengetahuan merupakan fitur bagi pakar untuk melakukan validasi pengetahuan yang dibuat oleh alumni. Fitur ini bertujuan melakukan pengecekan penulisan sudah sesuai atau belum dengan kaidah EYD (Ejaan Yang Disempurnakan), tidak mengandung unsur negatif terhadap SARA (Suku, Agama, Ras, Antar Golongan), dan terkait terhadap kategori bidang kepakaran. Jika sudah sesuai maka pengetahuan tersebut dapat diterbitkan untuk dibaca oleh alumni lainnya. Fitur dokumen merupakan firtur untuk membagikan pengetahuan explicit karyawan dalam bentuk dokumen elektronik yang di upload kedalam sistem. Dokumen tersebut berupa Standar Operasional Prosedur (SOP), laporan kegiatan, laporan hasil rapat, dan daftar mitra. Fitur agenda kegiatan untuk alumni membuat agenda kegiatan seperti kegiatan lokakarya, seminar, dan kegiatan lainnya. Fitur agenda rapat untuk mengingatkan dan mendokumentasikan waktu agenda rapat karyawan. Fitur mitra untuk daftar mitra ALPHA-I. Fitur ini dibuat untuk mendokumentasikan mitra (partner) yang bekerjasama dengan organisasi ALPHA-I. Fitur konsultasi untuk alumni bisa berkonsultasi dengan pakar yang sesuai bidangnya. Fitur tanya jawab untuk informasi mengenai sistem KMS ini. Fitur kontak merupakan fitur untuk menghubungi admin KMS ini, jika terjadi kendala teknis seperti lupa akun atau tidak bisa login.

\section{Kebutuhan non-fungsional}

Kebutuhan non-fungsional meliputi kebutuhan tekniks yang digunakan saat pembuatan sistem, kemudahan penggunaan sistem (user friendly), sistem beroperasi secara online terkait dengan update pengetahuan. Sistem dapat diakses pada browser seperti google chrome, mozill firefox, dan lainnya. Faktor kemanan (security) sistem menggunakan proses login bagi pengguna yang akan mengakses KMS ini. Pengguna yang ingin mengakses KMS ini harus memiliki akun terlebih dahulu.

\section{Perancangan sistem}

Desain KMS ALPHA-I dilakukan dengan menggunakan pendekatan berorientasi obyek yaitu Unfied Modeling Language (UML). UML merupakan bahasa yang terstandarisasi yang digunakan untuk memodelkan suatu sistem dengan pendekatan Object Oriented Programming (OOP) atau pendekatan berorientasi obyek (Kendal, 2011). Konsep OOP dasar sebagai berikut:

\section{Encapsulation \\ 2. Inheritance \\ 3. Polymorphisme}

\section{A. Use case diagram}

Use case diagram berfungsi menggambarkan aktor siapa saja yang berhak melakukan apa pada proses apa yang ada pada sistem, dengan adanya suatu interaksi antara satu atau lebih aktor dengan sistem. Aktor yang terlibat dan deskripsi use case pada sistem manajemen pengetahuan di organisasi ALPHA-I dapat dilihat pada Tabel 2 dan deskripsi use case pada Tabel 3 . 
Tabel 2. Aktor yang terlibat

\begin{tabular}{|c|c|c|}
\hline No & Aktor & Keterangan \\
\hline 1 & Alumni & $\begin{array}{l}\text { Melihat status validasi pengetahuan yang telah } \\
\text { dibuat, menambahkan pengetahuan baru, } \\
\text { menambahkan konsultasi, menambahkan } \\
\text { agenda kegiatan, melihat tanya jawab (FAQ), } \\
\text { menambahkan kontak (pesan) kepada admin } \\
\text { dan mengubah data profil. }\end{array}$ \\
\hline 2 & Karyawan & $\begin{array}{l}\text { Melihat profil alumni, mengelola dokumen } \\
\text { pengetahuan karyawan, mengelola agenda rapat, } \\
\text { mengelola mitra, melihat tanya jawab (FAQ), } \\
\text { dan mengubah data profil. }\end{array}$ \\
\hline 3 & Pakar & $\begin{array}{l}\text { Memvalidasi pengetahuan alumni, memberi } \\
\text { jawaban konsultasi alumni, melihat agenda } \\
\text { kegiatan alumni, dan mengubah data profil. }\end{array}$ \\
\hline 4 & Admin & $\begin{array}{l}\text { Mengelola data profil, pengetahuan, dokumen, } \\
\text { konsultasi, agenda rapat, agenda kegiatan, tanya } \\
\text { jawab, dan kontak. }\end{array}$ \\
\hline
\end{tabular}

Tabel 2 menjelaskan aktor yang terlibat dalam penggunakan KMS ini terdiri atas empat yaitu Alumni, Karyawan, Pakar, dan Admin. Setiap aktor memiliki hak akses yang berbeda.

Tabel 3. Deskripsi use case

\begin{tabular}{|c|c|c|}
\hline No & Use case & Deskripsi \\
\hline 1 & $\begin{array}{l}\text { Validasi } \\
\text { pengetahuan }\end{array}$ & $\begin{array}{l}\text { Proses validasi konten yaitu melihat status } \\
\text { validasi pengetahuan yang dibuat oleh } \\
\text { alumni, memberikan masukan pengetahuan } \\
\text { dari alumni, dan menerbitkan pengetahuan } \\
\text { alumni. Proses validasi pengetahuan yang } \\
\text { dibuat alumni dilakukan oleh pakar. }\end{array}$ \\
\hline 2 & $\begin{array}{l}\text { Mengelola } \\
\text { pengetahuan }\end{array}$ & $\begin{array}{l}\text { Proses pengelolaan pengetahuan yaitu } \\
\text { menambahkan (membuat), melihat, } \\
\text { mencari, membaca mengubah, dan } \\
\text { menghapus pengetahuan. }\end{array}$ \\
\hline 3 & $\begin{array}{l}\text { Mengelola } \\
\text { dokumen }\end{array}$ & $\begin{array}{l}\text { Proses pengelolaan dokumen untuk } \\
\text { karyawan yaitu menambahkan, melihat, } \\
\text { mencari, mengubah, dan menghapus } \\
\text { dokumen. }\end{array}$ \\
\hline 4 & $\begin{array}{l}\text { Mengelola } \\
\text { konsultasi }\end{array}$ & $\begin{array}{l}\text { Proses pengelolaan konsultasi yaitu } \\
\text { menambahkan, melihat, mencari, } \\
\text { mengubah, dan menghapus konsultasi. }\end{array}$ \\
\hline 5 & $\begin{array}{l}\text { Mengelola } \\
\text { tanya jawab } \\
(F A Q)\end{array}$ & $\begin{array}{l}\text { Proses pengelolaan tanya jawab meliputi } \\
\text { menambahkan, melihat, menjawab, } \\
\text { mengubah, dan menghapus tanya jawab. }\end{array}$ \\
\hline 6 & $\begin{array}{l}\text { Mengelola } \\
\text { agenda rapat }\end{array}$ & $\begin{array}{l}\text { Proses pengelolaan agenda rapat untuk } \\
\text { karyawan yaitu menambahkan, melihat, } \\
\text { mencari, mengubah, dan mengapus agenda } \\
\text { rapat. }\end{array}$ \\
\hline 7 & $\begin{array}{l}\text { Mengelola } \\
\text { agenda } \\
\text { kegiatan }\end{array}$ & $\begin{array}{l}\text { Proses pengelolaan agenda kegiatan untuk } \\
\text { alumni yaitu menambahkan, melihat, } \\
\text { mencari, mengubah, dan menghapus } \\
\text { agenda kegiatan }\end{array}$ \\
\hline 8 & $\begin{array}{l}\text { Mengelola } \\
\text { mitra }\end{array}$ & $\begin{array}{l}\text { Proses pengelolaan mitra ALPHA-I yaitu } \\
\text { menambahkan, melihat, mencari, } \\
\text { mengubah, dan mengapus mitra. }\end{array}$ \\
\hline 9 & $\begin{array}{l}\text { Mengelola } \\
\text { kontak }\end{array}$ & $\begin{array}{l}\text { Proses pengelolaan kontak (pesan) untuk } \\
\text { karyawan yaitu menambahkan, melihat, } \\
\text { mencari, dan menghapus kontak. }\end{array}$ \\
\hline 10 & $\begin{array}{l}\text { Mengelola } \\
\text { pengguna }\end{array}$ & $\begin{array}{l}\text { Proses pengelolaan data yaitu } \\
\text { menambahkan, melihat, mencari, } \\
\text { mengubah, dan menghapus profil. }\end{array}$ \\
\hline
\end{tabular}

Tabel 3 menjelaskan deskripsi use case. Setiap use case memiliki perbedaan antara satu use case dengan use case lainnya. Use case admin dapat dilihat pada Gambar 3.

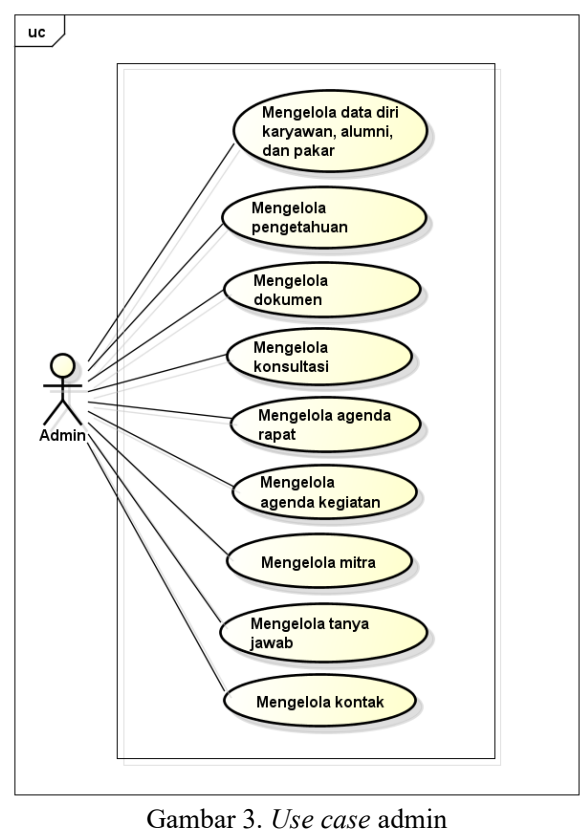

Gambar 3 menjelaskan bahwa aktor admin memiliki hak akses untuk mengelola data diri, mengelola pengetahuan alumni, mengelola dokumen karyawan, mengelola konsultasi, mengelola agenda rapat, mengelola agenda kegiatan, mengelola mitra, mengelola tanya jawab, dan mengelola kontak. Use case alumni dapat dilihat pada Gambar 4.

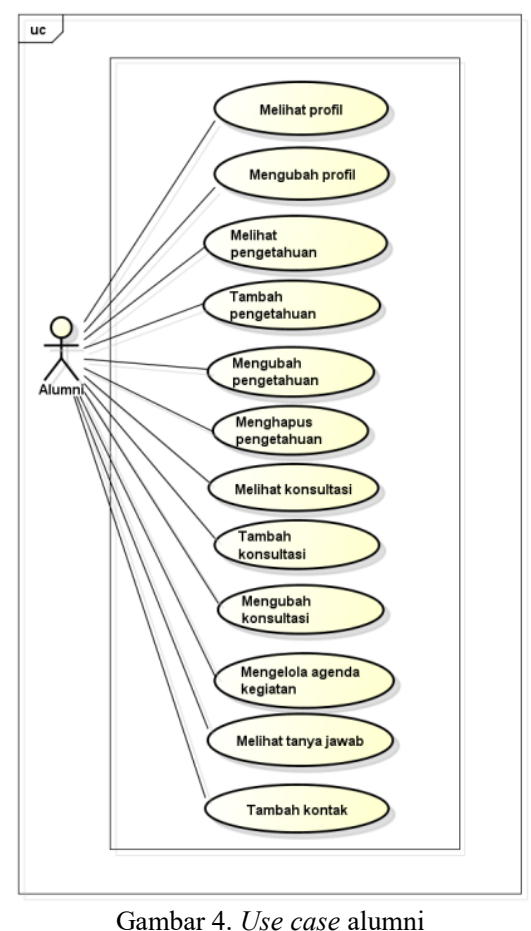

Gambar 4 menjelaskan bahwa aktor alumni memiliki hak akses untuk melihat profil, mengubah profil, melihat pengetahuan, tambah pengetahuan, mengubah pengetahuan, menghapus pengetahuan, 
melihat konsultasi, tambah konsultasi, mengubah konsultasi, mengelola agenda kegiatan, melihat tanya jawab, dan tambah kontak. Use case karyawan dapat dilihat pada Gambar 5.

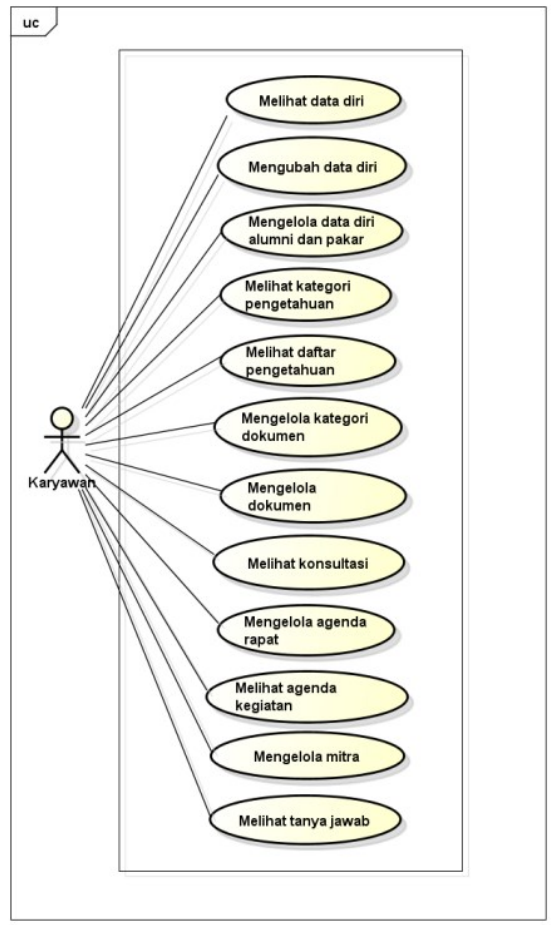

Gambar 5. Use case karyawan

Gambar 5 menjelaskan bahwa aktor karyawan memiliki hak akses untuk melihat data diri, mengubah data diri, mengelola data diri alumni dan pakar, melihat kategori pengetahuan, melihat daftar pengetahuan, mengelola kategori dokumen, mengelola dokumen, melihat konsultasi, mengelola agenda rapat, mengelola agenda kegiatan, mengelola mitra, dan melihat tanya jawab.

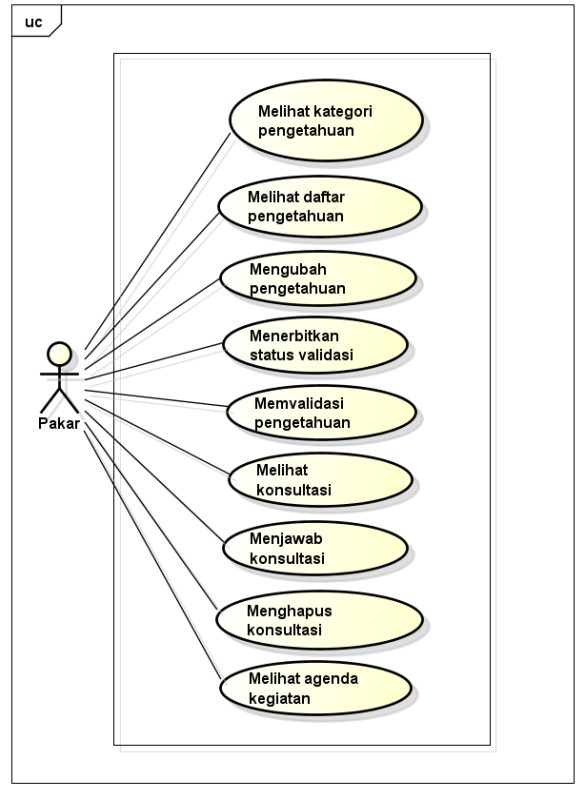

Gambar 6. Use case pakar
Gambar 3 menjelaskan bahwa aktor pakar memiliki hak akses untuk melihat kategori pengetahuan, melihat daftar pengetahuan, mengubah pengetahuan, menerbitkan status validasi, memvalidasi pengetahuan, melihat konsultasi, menjawab konsultasi, menghapus konsultasi, dan melihat agenda kegiatan.

B. Rancangan arsitektur sistem manajemen pengetahuan

Rancangan arsitektur sistem manajemen pengetahuan dari organisasi ALPHA-I terdiri atas enam lapisan. Rancangan arsitektur ini diadopsi dari arsitektur (Awad \& Ghaziri, 2010). Berikut ini rancangan arsitektur KMS ALPHA-I yang dapat dilihat pada Gambar 4.

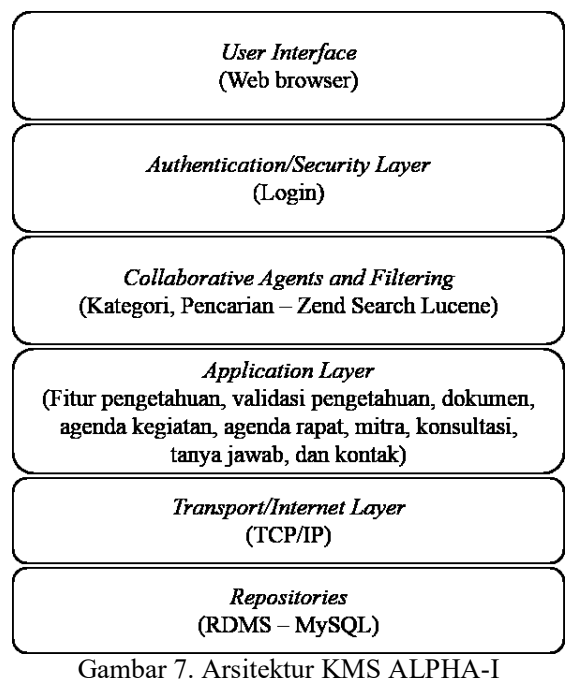

Rancangan arsitektur pada Gambar 7 dapat dijelaskan sebagai berikut:

a. User Interface

Lapisan atarmuka merupakan lapisan teratas antara sistem dengan pengguna. KMS ini dirancang berbasis web. Tujuannya agar pengguna dapat mengakses sistem kapan dan dimana saja selama pengguna tersambung jaringan internet.

b. Authentication/Security Layer

Lapisan ini mengatur keamanan dari KMS ini melalui mekanisme login. Pengguna harus memulai dengan login untuk mengakses fitur-fitur yang ada pada sistem ini. Hak akses pada sistem ini terbagi menjadi empat yaitu: alumni, karyawan, pakar, dan admin. Setiap kelompok memilik akses yang berbeda terhap konten di dalam sistem ini.

c. Collaborative Agents and Filtering

Lapisan ini digunakan untuk meminta data atau pengetahuan sesuai dengan permintaan, pencarian, kategori, dan sebagainya. Pengguna dapat menggunakan fitur kategori, dan pencarian untuk mendapatkan pengetahuan yang diinginkan. Pencarian pada KMS ini menggunakan library mesin pencarian Zend Search Lucene. 


\section{d. Application Layer}

Lapisan ini merupakan tempat fitur-fitur untuk mendukung proses pengetahuan berada. Aplikasi tersebut meliputi fitur pengetahuan, validasi pengetahuan, dokumen, agenda kegiatan, agenda rapat, mitra, konsultasi, tanya jawab, dan kontak.

\section{e. Transport/Internet Layer}

Lapisan transportasi pada $\mathrm{kms}$ ini menggunakan protocol TCP/IP. Protokol TCP/IP digunakan untuk menyalurkan paket-paket data yang meliputi dokumen, arsip konsultasi, dan pengetahuan.

\section{f. Repositories}

Lapisan ini merupakan tempat penyimpanan seluruh konten yang ada di kms ini meliputi basis data pengetahuan, dokumen, dan arsip konsultasi. Relational Database Management System (RDMS) yang dirancang menggunakan MySQL.

Sistem manajemen pengetahuan yang dibuat menggunakan framework bahasa pemrograman PHP dengan konsep MVC (Model View Controller). MVC merupakan metode yang memisahakan bagian data (model), tampilan (view), dan proses (controller) dalam membangun aplikasi (Prabowo, 2015). Basis data merupakan himpunan data yang saling berhubungan secara logis beserta deskripsinya untuk digunakan bersama-sama dan dibuat dalam memenuhi kebutuhan informasi di suatu tempat (Anisah \& Mayasari, 2016). PHP sebagai bahasa pemrograman dan MySQL sebagai database nya berbasis open source (sumber terbuka) atau gratis untuk digunakan. Bahasa pemrograman PHP akan berguna untuk proyek kecil dan besar (Bounnady, Phanthavong, Pathoumvanh dkk, 2016). Framework PHP dari KMS ini menggunakan PHP 5 yang sudah mendukung beberapa konsep OOP. Berikut ini merupakan tampilan dari KMS ALPHA-I yang telah dibuat dapat dilihat pada Gambar 8 dan Gambar 9.
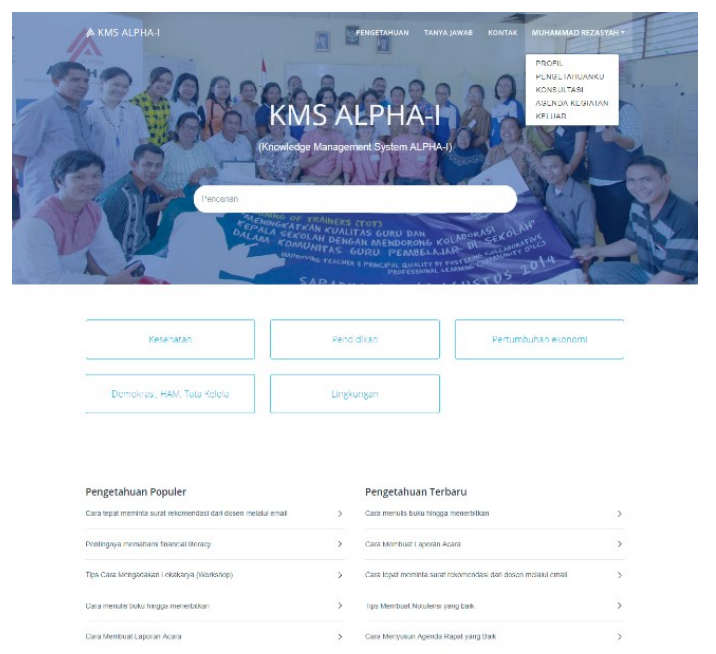

Gambar 8. Halaman tacit alumni

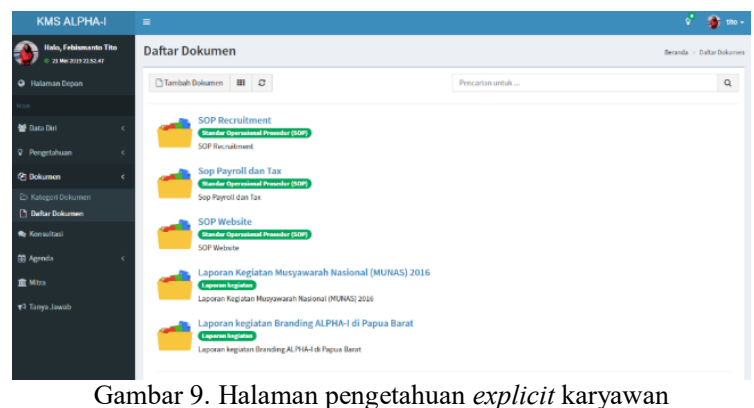

KMS ALPHA-I diinstalasi ke server agar dapat diakses via internet. Instalasi selesai dilakukan, KMS ALPHA-I bisa digunakan. Alamat yang digunakan dalam mengakses KMS ALPHA-I adalah http://172.104.188.95. Pada proses selanjutnya dilakukan dengan memasang aplikasi KMS ALPHA-I pada Apache2 web server dan RDBMS MySQL di server. Pengguna dapat melihat desain antar muka dapat mengakses dengan menggunakan web browser (mozilla, google chrome dan internet explorer).

\subsection{Verifikasi dan Validasi Sistem Manajemen Pengetahuan}

Tahapan ini dilakukan untuk mengevaluasi apakah Sistem Manajemen Pengetahuan memenuhi kriteria atau tidak (Rahmatia \& Surendro, 2013). Pengetahuan telah dilakukan verifikasi melalui penjelasan oleh pakar dengan hasil pengetahuan tacit dan explicit yang dimasukkan adalah benar merupakan pengetahuan alumni dan karyawan di organisasi ALPHA-I. Hasil verifikasi pengetahuan tacit alumni dan pengetahuan explicit karyawan dapat dilihat pada Tabel 4 dan Tabel 5.

\begin{tabular}{|c|c|c|c|}
\hline No. & Kategori & Pengetahuan & Status \\
\hline 1 & $\begin{array}{l}\text { Demokrasi } \\
\text { HAM dan } \\
\text { Tata Kelola }\end{array}$ & $\begin{array}{l}\text { Mengenal Hak Asasi Manusia } \\
\text { (HAM) }\end{array}$ & Valid \\
\hline 2 & Pendidikan & $\begin{array}{l}\text { Merawat kebhinekaan } \\
\text { Indonesia sejak dini }\end{array}$ & Valid \\
\hline 3 & Kesehatan & $\begin{array}{l}\text { Urun biaya dan selisih biaya, } \\
\text { solusi bagi JKN? }\end{array}$ & Valid \\
\hline 4 & $\begin{array}{l}\text { Pertumbuhan } \\
\text { Ekonomi }\end{array}$ & $\begin{array}{lr}\text { Konsep } & \text { pembangunan } \\
\text { infrastruktur } & \text { dalam } \\
\text { pembangunan } & \text { ekonomi }\end{array}$ & Valid \\
\hline 5 & $\begin{array}{l}\text { Lingkungan } \\
\text { Hidup }\end{array}$ & $\begin{array}{l}\text { Pentingnya sanitasi yang } \\
\text { layak di sekolah }\end{array}$ & Valid \\
\hline
\end{tabular}

Tabel 5. Verifikasi Pengetahuan Explicit

\begin{tabular}{clll}
\hline No. & Kategori & Pengetahuan & Status \\
\hline 1 & SOP & SOP Website & Valid \\
2 & Laporan & Laporan kegiatan Musyawarah & Valid \\
& Kegiatan & Nasional (MUNAS) 2017 & \\
3 & Laporan & Laporan rapat MUNAS 2017 & Valid \\
& Hasil Rapat & & \\
4 & Daftar Mitra & Daftar mitra ALPHA-I & Valid \\
5 & Press & Pernyataan sikap ALPHA-I & Valid \\
& Release & tentang urgensi persatuan & \\
& & bangsa dan penghormatan & \\
& & terhadap proses hukum pasca & \\
& & pemilu 2019 & \\
\hline
\end{tabular}


Tahap validasi dilakukan dengan cara menguji fungsionalitas sistem menggunakan Metode Black box testing. Metode Black box testing merupakan pengujian yang memfokuskan pada spesifikasi fungsional perangkat lunak (Khan, 2011). Pengujian menggunakan metode Blackbox testing dapat dililhat pada Tabel 6. Pengujian berdasarkan fitur utama KMS yang terdiri dari fitur mencari pengetahuan, mengelola pengetahuan, dan mengelola dokumen. Hasil pengujian yang telah dilakukan menyatakan bahwa semua fungsi pada sistem berjalan dengan baik.

\begin{tabular}{|c|c|c|c|c|}
\hline Deskripsi & Kondisi & Uji & Hasil & Status \\
\hline $\begin{array}{l}\text { Mencari } \\
\text { pengetahuan }\end{array}$ & $\begin{array}{l}\text { Memilih } \\
\text { menu cari } \\
\text { pengetah } \\
\text { uan }\end{array}$ & $\begin{array}{l}\text { Mengisi kata } \\
\text { kunci } \\
\text { pencarian }\end{array}$ & $\begin{array}{l}\text { Menampilkan } \\
\text { pengetahuan } \\
\text { yang dicari }\end{array}$ & Valid \\
\hline $\begin{array}{l}\text { Menambah } \\
\text { pengetahuan }\end{array}$ & $\begin{array}{l}\text { Memilih } \\
\text { menu } \\
\text { pengetah } \\
\text { uanku }\end{array}$ & $\begin{array}{l}\text { Menambah } \\
\text { pengetahuan }\end{array}$ & $\begin{array}{l}\text { Menampilkan } \\
\text { pengetahuan } \\
\text { yang baru }\end{array}$ & Valid \\
\hline $\begin{array}{l}\text { Mengubah } \\
\text { pengetahuan }\end{array}$ & $\begin{array}{l}\text { Memilih } \\
\text { menu } \\
\text { pengetah } \\
\text { uan }\end{array}$ & $\begin{array}{l}\text { Mengubah } \\
\text { pengetahuan }\end{array}$ & $\begin{array}{l}\text { Menampilkan } \\
\text { informasi } \\
\text { pengetahuan } \\
\text { berhasil } \\
\text { diubah }\end{array}$ & Valid \\
\hline $\begin{array}{l}\text { Menghapus } \\
\text { pengetahuan }\end{array}$ & $\begin{array}{l}\text { Memilih } \\
\text { menu } \\
\text { pengetah } \\
\text { uan }\end{array}$ & $\begin{array}{l}\text { Menghapus } \\
\text { pengetahuan }\end{array}$ & $\begin{array}{l}\text { Menampilkan } \\
\text { informasi } \\
\text { pengetahuan } \\
\text { berhasil } \\
\text { dihapus }\end{array}$ & Valid \\
\hline $\begin{array}{l}\text { Menambah } \\
\text { dokumen }\end{array}$ & $\begin{array}{l}\text { Memili } \\
\mathrm{h} \text { menu } \\
\text { dokume } \\
\mathrm{n}\end{array}$ & $\begin{array}{l}\text { Menambah } \\
\text { dokumen }\end{array}$ & $\begin{array}{l}\text { Menampilka } \\
\mathrm{n} \text { dokumen } \\
\text { yang baru }\end{array}$ & Valid \\
\hline $\begin{array}{l}\text { Mengubah } \\
\text { dokumen }\end{array}$ & $\begin{array}{l}\text { Memili } \\
\mathrm{h} \text { menu } \\
\text { dokume } \\
\mathrm{n}\end{array}$ & $\begin{array}{l}\text { Mengubah } \\
\text { dokumen } \\
\text { yang dipilih }\end{array}$ & $\begin{array}{l}\text { Dokumen } \\
\text { yang diubah } \\
\text { berhasil } \\
\text { disimpan }\end{array}$ & Valid \\
\hline $\begin{array}{l}\text { Menghapus } \\
\text { dokumen }\end{array}$ & $\begin{array}{l}\text { Memili } \\
\mathrm{h} \text { menu } \\
\text { dokume } \\
\mathrm{n}\end{array}$ & $\begin{array}{l}\text { Menghapus } \\
\text { dokumen }\end{array}$ & $\begin{array}{l}\text { Dokumen } \\
\text { terhapus } \\
\text { dari menu } \\
\text { dokumen }\end{array}$ & Valid \\
\hline
\end{tabular}

\section{KESIMPULAN}

Penelitian ini telah berhasil mengembangkan sistem manajemen pengetahuan di organisasi ALPHA-I. Sistem manajemen pengetahuan dikembangkan menggunakan metode yang diadopsi dari KMSLC. Sistem ini menggunakan framework bahasa pemrograman PHP dengan konsep MVC yang didukung dengan RDBMS MySQL.

KMS ALPHA-I ini memiliki fitur-fitur untuk mendukung proses manajemen pengetahuan yang terdiri atas pengetahuan, dokumen, validasi pengetahuan, konsultasi, agenda kegiatan, agenda rapat, mitra, tanya jawab dan kontak. Hasil uji coba KMS ini menunjukkan bahwa semua fungsi pengguna sudah terpenuhi dan berfungsi dengan baik.

\section{DAFTAR PUSTAKA}

ALIPOUR, F., IDRIS, K., \& KARIMI, R., 2011. Knowledge Creation and Transfer : Role of Learning Organization. International Journal of Busines Administration. 2:61-67.

ANISAH, \& MAYASARI., M.S., 2016. Desain Database Sistem Informasi Penerimaan Peserta Didik Baru Pada Selective English Course. Jurnal SIMETRIS. 7(1):183-190.

AWAD, E.M., \& GHAZIRI, H.M., 2010. Knowledge Management. New Jersey (US): Pearson Education Pr.

BECERRA-FERNANDEZ, I., \& SABHERWAL, R., 2010. Knowledge Management Systems and Process. New York (US): M.E.Sahrpe Pr.

BOLISANI, E., \& HANDZIC, M., 2015. Advances in Knowledge Management: Celebrating Twenty Years of Research and Practice. Italy (ITA): Springer Publishing.

BOUNNADY, K., PHANTHAVONG, K., PATHOUMVANH, S., \& SIHALATH, K., 2016. Comparison the processing speed between PHP and ASP.NET. Chiang Ma (TH): 2016 13th International Conference on Electrical Engineering/Electronics, Computer, Telecommunications and Information Technology (ECTI-CON).

[KEMENKUMHAM] Kementerian Hukum dan Hak Asasi Manusia. 2014. Peraturan Menteri Hukum dan Hak Asasi Manusia Republik Indonesia nomor 6 tentang Pengesahan Badan Hukum Perkumpulan. Jakarta (ID): MENKUMHAM RI.

KENDAL, K.E., \& KENDAL, J.E., 2011. System Analysis and Design. 8th ed. New Jersey (US): Pearson Education Pr.

KHAN, M.E., 2011. Different Approach to Blackbox Testing Technique for Finding Error. International Journal of Software Engineering \& Applications (IJSEA). 2(4): 31-40.

KIRANA， C., \& WAHDANIYAH, R., 2018. Implementasi Aplikasi Alumni Berbasis Mobile Application. Jurnal Edukasi dan Penelitian Informatika. 4(2):179-183.

NARENDRA UP, PRADEEP BS, PRABHAKAR M. 2017. Externalization of tacit knowledge in a knowledge management system using chat bots. Bandung (ID): 2017 3rd International Conference on Science in Information Technology (ICSITech).

RAHMATIA, D., \& SURENDRO, K., 2013. Knowledge Management System Design Model for Smart Enterprise. Jakarta (ID): International Conference on ICT for Smart Society. 
SISWANTO, I., 2014. Peran manajemen pengetahuan dan pembelajaran organisasi terhadap inovasi produk pada usaha kecil menengah olahan pangan di Bogor [tesis]. Bogor (ID): Institut Pertanian Bogor.

PRABOWO, D., 2015. Website E-Commerce Menggunakan Model View Controller (MVC) dengan Framework Codeigniter Studi Kasus: Toko Miniatur. Jurnal Ilmiah DASI. 16(1):23-29.

PRAYITNO, J., KUSRINI, \& SUDARMAWAN. 2017. Teknologi informasi dalam mendukung knowledge management di organisasi alumni. Seminar Nasional APTIKOM (SEMNASTIKOM). Jayapura. 
Halaman ini sengaja dikosongkan 